\title{
Acquired tolerance for minor histocompatibility antigens after HLA identical bone marrow transplantation
}

\author{
Marleen de Bueger, Astrid Bakker, and Els Goulmy \\ Department of Immunohaematology and Bloodbank, Unıversity Hospital Leiden, Rınnsburgerweg 10, 2333 \\ AA Leiden, The Netherlands
}

Key words CTLp frequency, non-HLA antigens, limiting dilution analysis, graft-versus-host disease, epithelial cells

\begin{abstract}
Skin tissue of a healthy chimera 7 years after HLA identical bone marrow transplantation was found to express a minor histocompatibility $(\mathrm{mH})$ antigen against which cytotoxic $\mathrm{T}$ lymphocytes (CTLs) had been discovered at a time of acute graft-versus-host disease (aGVHD). We were prompted to investigate the apparent tolerance to this persistent $\mathrm{mH}$ antigen and used limiting dilution analysis to monitor in vitro anti-host CTL responses in time after bone marrow transplantation. A high anti-host CTL precursor frequency was found during acute GVHD, declining in time until beyond detection level in the heakhy chimera 7 years after transplantation. In this case report (i) CTL precursor frequencies are used for the first time to monitor in vitro tolerance induction to persistent host $\mathrm{mH}$ antigens after HLA identical BMT in man; and (ii) it is shown that LDA may be a potential tool for quantification and specificity analysis of CTL responses to $\mathrm{mH}$ antigens.
\end{abstract}

\section{Introduction}

The mechanısms underlyıng induction and maıntenance of tolerance after allogeneic bone marrow transpiantation (BMT) are still unclear (1) Although tolerance after MHC-Identical BMT has been addressed by some authors $(2-6)$, the issue is complicated because analysis of reactivity to minor histocompatıbility $(\mathrm{mH})$ antigens is hampered by the absence of a primary in vitro graft-versus-host response before transplantation (5) In man, it is established that in patients having received HLA Identical bone marrow, $\mathrm{mH}$ antigen reactive cytotoxic $T$ lymphocytes (CTLS, $6-8), T_{h}$ cells (9), and specific (5) as well as non-specific (10) suppressor cells can be detected However, whether, and if so how, these respective cell types can account for the development of graft - host tolerance is controversial $(3,4)$

Here we report on a patient who enabled us to address the issue of acquired tolerance after HLA genotypically identical but $\mathrm{mH}$ antigen mismatched BMT His peripheral blood leukocytes (PBL) studied in vitro at a time of acute graft-versus-host disease (aGVHD) Contained host reactive CTLś recognizing a self HLA class I restricted $\mathrm{mH}$ determinant $\mathrm{HA}-3$ (6), detectable not only on the patient's pre-BMT PBL but also on his post-BMT skın-derived keratınocytes and fibroblasts. Seven years post-BMT, this full donor chimera was in good health and must have acquired tolerance to host $\mathrm{mH}$ antigens such as $\mathrm{HA}-3$, shown to be persistently expressed in patient skın tissue after BMT We were prompted to investigate in vitro anti-host CTL reactivity in time using limiting dilution analysis (LDA) and found that (i) CTL responses directed to host $\mathrm{mH}$ antigens after BMT could be measured in a primary in vitro assay, (II) split-well analysis of primary antı-host LD cultures allowed analysis of the repertorre of $\mathrm{mH}$ antigen reactive CTLs triggered by BMT, and (IIi) the anti-host CTLp frequency in this patient, high durıng aGVHD, declined in time to beyond detection level at 7 years post-BMT, and therewith paralleled the in vivo state of tolerance.

\section{Methods}

Patient

A 29 year old male AML patient recelved non-depleted bone marrow of his HLA identical (HLA-A1,-A11,-B8,-B60,-CW3,-DR2, -DR3), MLR-negative, non-transfused brother Rapid engraftment followed by aGVHD grade II of primarily gut and liver (diagnosed day 26) was treated with decreasing amounts of prednisone Graft-versus-host reactıons revived at day 85 involving skın, gut, and liver After renewed prednisone treatment (days 124-134) graft-versus-host reactivities definitively disappeared, this patient 
is at present in apparently good health 9 years post-BMT FACS analysis of the patient's PBL revealed high frequencies of monocytes shortly post-BMT $71 \%$ on day 24 and $51 \%$ on day 141 An inversed CD4/CD8 ratıo was found (day 24,028 ) due to both an increase in $\mathrm{CD}^{+}$and a decrease in $\mathrm{CD} 4^{+} \mathrm{T}$ cells At 7 years post-BMT the inversed ratio persisted $(038)$ whereas $B$ cell and monocyte values had normalized The presumed state of full donor chımerism could not be confirmed by restriction fragment length polymorphism because of lack of discrimınative markers However, the absence of any host-derived cells in the $B$ and $T$ cell compartment could be shown as early as day 24 post-BMT by using a cellular marker (not shown)

\section{Keratınocyte and fibroblast cultures}

Keratınocytes were isolated from patıent, donor, and third party arm skin biopsies, and cultured as previously described (11) Wells of microtiter plates were coated with layers of cultured keratınocytes and, after ${ }^{51} \mathrm{Cr}$-labelıng, used as adherent target cells in the cell-mediated lympholysis (CML) assay (11) The patient's skin-derived fibroblasts were cultured in DMEM (Flow) $+5 \%$ FCS and were also used as adherent targets in CML (12)

\section{Host-reactive $T$ cell Iines}

PBL at several time points after BMT were repeatedly stmulated with patient post-BMT PBL to yield anti-host CTL lınes as described elsewhere (6) From a day 24 post-BMT CTL lıne, an anti-host CTL clone ( 5 Ho11) was derived, which showed HLA.A1 restricted recognition of a non-HLA determinant designated as HA-3 (6) T cell lines generated in this way from 7 years post-BMT PBL contained no cytotoxicity towards the patient's pre-BMT phytohemagglutının (PHA) blasts (not shown)

\section{Limiting dilution analysis}

Graded numbers of responder cells (156-4 × $10^{4}$ cells/well) were set up 24-plicate in round-bottomed microtiter plates in the presence of irradiated stımulator cells in $200 \mu$ of culture medium (RPMI 1640, 15\% human serum) with $20 \mathrm{U} \mathrm{rlL}-2 / \mathrm{ml}$ (13) Stmulator cells were etther polymorphonuclear cells (PMNC) $\left(5 \times 10^{4} /\right.$ well rad) or Epstein - Barr virus Iymphocyte cell line $(E B V-L C L)\left(5 \times 10^{3} /\right.$ well, $\left.5000 \mathrm{rad}\right)$ After 5 days $100 \mu \mathrm{l} \mathrm{con-}$ taınıng $15 \cup \mathrm{rlL}-2 / \mathrm{ml}$ was refreshed and at day 7 the wells were assayed for cytotoxicity towards PHA blasts in a standard ${ }^{51} \mathrm{Cr}$ release assay Cultures were considered positive when showing lysis exceeding mean spontaneous release (24 wells) plus 3 SD LD weils never contaned any non specific cytotoxicity of autologous ( $=$ responder) PHA blasts Frequencles of CTLp and 95\% confidence intervals were calculated using the minimum $\chi^{2}$, maximum likelihood, and jacknife methods in some experiments the wells were split and $50 \%$ of the weils' contents was assayed for cytotoxicity Host reactive wells were expanded using present EVB-BLCLs $\left(10^{5} / \mathrm{ml}, 5000 \mathrm{rad}\right)$ and autologous donor $\mathrm{PBL}(10 \% \mathrm{ml}, 3000 \mathrm{rad})$ in culture medium with $2 \% \mathrm{HP}$ IL 2 (Biotest) One or two stimulation cycles were needed to obtain enough of each oligoclonal CTL culture to test rianel reactivity and reactivity to host skin cells in a CML assay

\section{Results}

Minor antigen HA-3 specific lysis of host skin

The HA-2 specific, HLA-A1 restricted CTL clone 5 Ho1 1 obtained from the patient's PBL during aGVHD was tested for recognition

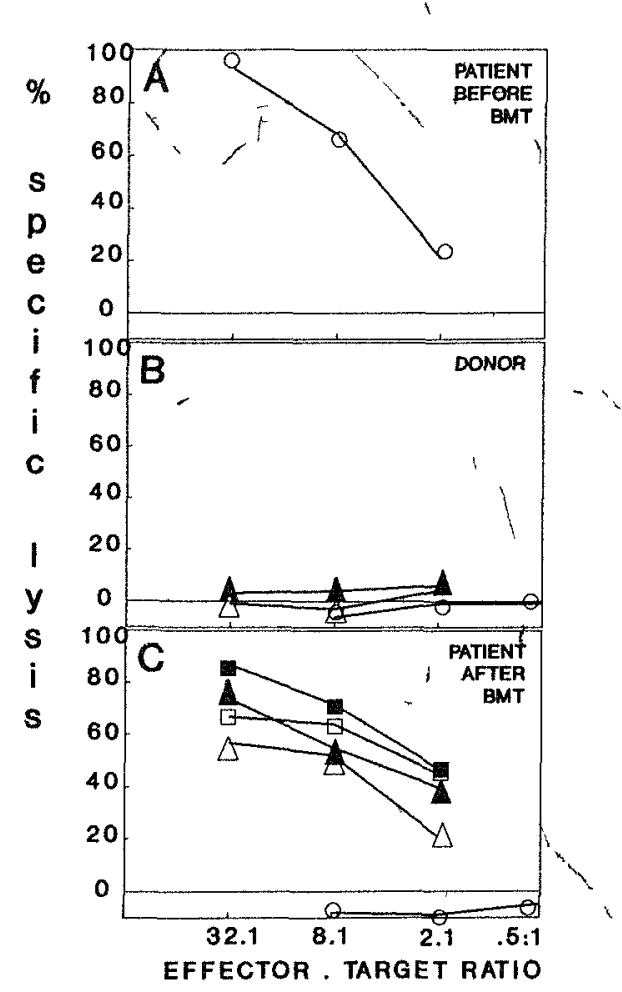

Fig. 1. Split chimerism for the HA-3 antigen after BMT The HA-3 specific HLA A1 restricted CTL clone $5 \mathrm{Ho} 11$ was tested in a $4 \mathrm{~h}^{51} \mathrm{Cr}$ release assay for lysis of PHA blasts (O), keratinocytes $(\Delta \boldsymbol{\Delta}+24 \mathrm{~h}$ $250 \mathrm{U} / \mathrm{ml} \mathrm{rIFN} \gamma)$, and fibroblasts $(\square, 24 \mathrm{~h} 250 \mathrm{U} / \mathrm{ml} \mathrm{rIFN} \gamma)$ of the HLA identical donor (B), and the patient before (A) and after BMT (C)

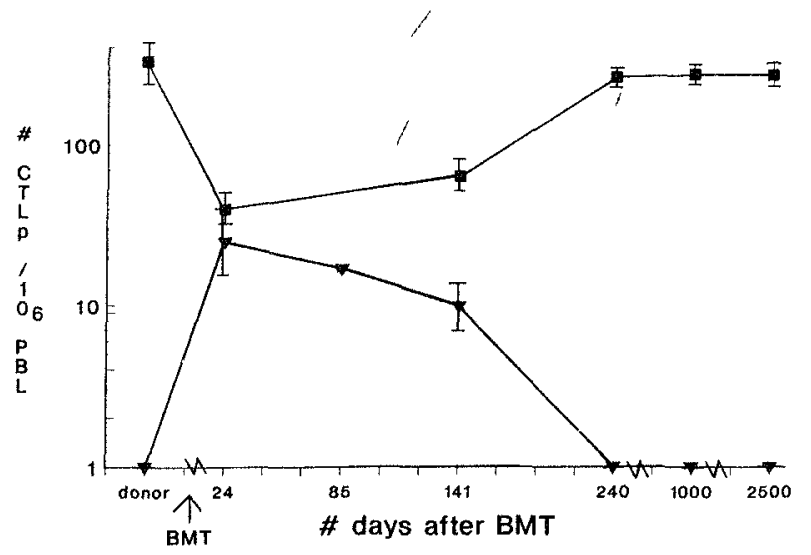

Fig. 2. Development of CTLp frequencies agarnst $m H$ and allo HLA antigens in time after HLA identical BMT CTLp frequencies represent mean values + SE of five experiments and were measured using PBL of the patient before BMT ( $)$ and PBL of an unrelated fully HLA musmatched individual (W)

of donor and patient post-BMT PHA blasts, keratınocytes, and fibroblasts, and of the patient's post BMT PHA blasts Figure 1 shows that the patient's PBL, expressing HA-3 before HLA identical BMT (A), had become HA-3 negative after BMT (C), as fits with complete hematopoiesis from the HA-3 negative, HLA Identical donor bone marrow (B) In contrast, the patient's post-BMT keratınocytes and fibroblasts, with or without previous Incubation with rIFN $\gamma$, were lysed by the anti-HA 3, HLA-A1 


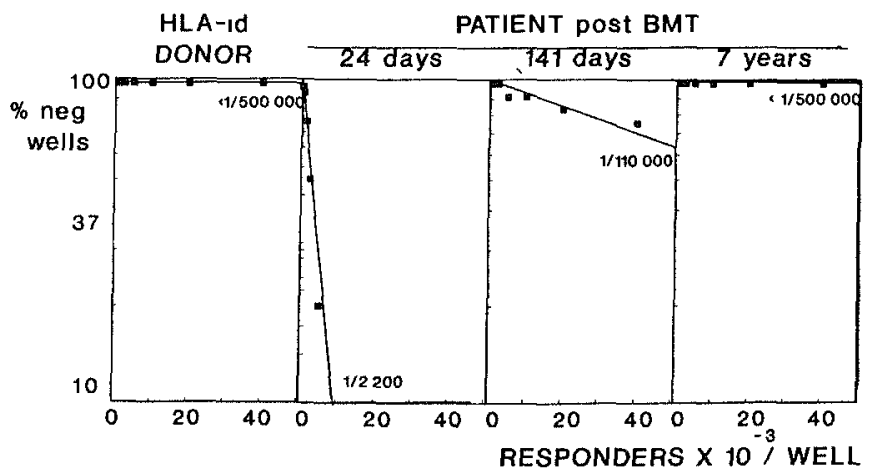

Fig. 3. Measurement of $\mathrm{mH}$ antigen reactive $\mathrm{CTL}$ precursors after $\mathrm{BMT}$ PBL of the donor and the patient post-BMT (days 24 and 141 , and 7 years) were tested as RC in LDA with patient post BMT EBVL-LCL as SC The percentage negative of 24 wells is presented and the calculated CTLP frequencles are given

restricted CTLS $(C)$, thus indicatıng the persistent expression of the $\mathrm{mH}$ antigen after BMT

Host and alloreactive CTL precursor frequencies after BMT

LD cultures were set up using several patient's post-BMT samples and unprimed donor PBL as responder ceils (RC) and patient pre-transplant PBL as stımulator cells (SC) The same RC were also stimulated with PBL of an unrelated HLA mismatched Individual In four of five experıments we observed the same trend of anti-host CTLp frequencies, in time (Fig 2) In the unprimed donor PBL a very low $(1 / 200,000-500,000)$ or undetectable frequency $(<1 / 500,000)$ against his HLA identical brother was found After BMT repopulating donor cells revealed a significant frequency of host specific CTL precursors The frequency of $\mathrm{mH}$ antigen reactive CTLp rapidly declined in time and could no longer be demonstrated in blood samples of 240 days -9 years after BMT (Fig 2) The CTLp frequency against allo-HLA antıgens revealed the reverse trend, being severely decreased shortly post-BMT, restoring in time to approach the allo-CTLp frequency found for the HLA identical donor ( $F$ ig 2) Since the absolute values of $\mathrm{mH}$ antigen reactive CTLp frequencies measured were low $(<1 / 29,000)$, we also used EBV-LCL to measure anti-host CTLp frequencies after BMT The same development in tıme was observed with significantly higher frequencies (Fig 3)

\section{Specificity of host-reactive CTLS after BMT}

From one LD' experıment using day 24 post-BMT PBL as RC and patient post-BMT PBL as SC, wells were split, screened for cytotoxicity of host PHA blasts and expanded Of 33 oligoclonal CTL lines obtàned from positive LD wells, 26 contained host specific CTLs ( 1 e lys's $>15 \%$ of patient post-BMT and $<1 \%$ of donor PHA blasts) The recognition pattern on PHA blasts from eight unrelated inaividuals each sharımg one HLA antigen with the responder cells are shown in Fig 4 The panel analysis $(n=16)$ indicaied that recognition could occur in the context of all self HLA class 1 antıgens ( $F / g$ 4C), although HLA-A1 appeared the predominant restriction antigen (Fig 4A and $B$ ) Testing cytotoxicity towards pairs of HLA-Identical HLA-A1 positive, HA-3 incompatible $(n=5)$, and HA-3 compatible $(n=3)$ siblings indicated that a large fraction of the HLA-A1 restricted CTL cultures might contain HA-3 like reactivity (one HA-3 incompatible pair is shown in Fig 4A),

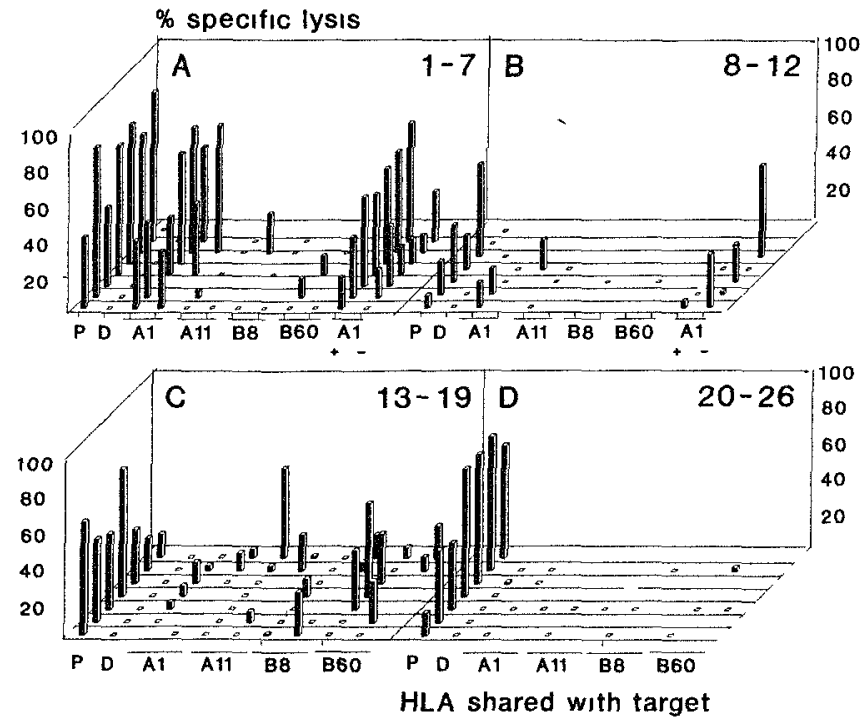

Fig. 4. Panel reactivity of cytolytic host reactive LD cultures Twenty-six oligoclonal CTL lines obtained from positive LD wells containing $25-40 \times 10^{3}$ of day $24 \mathrm{PBL}$ were tested for lysis of a panel of PHA blasts, including patient pre-BMT (P), donor (D), eight unrelated target cells sharing either HLA-A1, $-\mathrm{A} 11,-\mathrm{B} 8$ or -B60, and two target cells derived from an HLA-A1 ${ }^{+}, \mathrm{HA}-3$ disparate (Indicated,+- ) sibling pair $\mathrm{CTL}$ lines are presented according to possible HLA restriction A, B HLA A1, $C$ other, $D$ no panel reactivity Values of lysis observed at $E T=30$ are shown

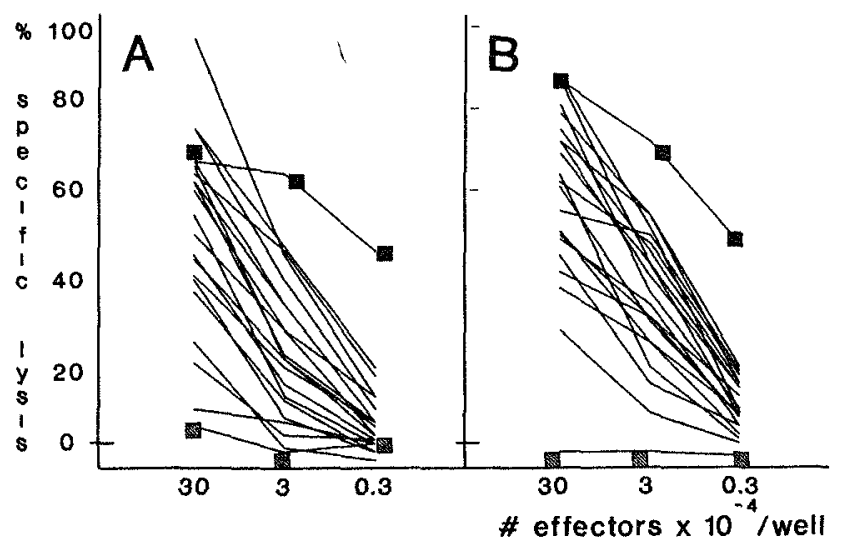

Fig. 5. Eighteen $C T L$ lines obtained from day $24 \mathrm{KD}$ cultures were tested for recognition of the patient's post-BMT cultured dermal fibroblasts (A untreated, B $25 \mathrm{U} / \mathrm{ml} \mathrm{HIFN}-\gamma, 48 \mathrm{~h}$ ) in a $4 \mathrm{~h}^{51} \mathrm{Cr}$ release assay LD wells had been expanded 2 weeks before usage as effectors $(\rightarrow$ ) The HA-3/HLA-A1 specific CTL clone 5 Hol1 (w) served as a positive and a HLA-87 specific CTL ine ( $\mathbb{N}$ ) as a negative control

Of the $26 \mathrm{CTL}$ lines obtained from LD wells, 18 were also tested for reactivity towards the patient's post-BMT dermal fibroblasts All CTL Ines to some extent lysed IFN- $\gamma$ treated as well as untreated fibroblasts ( $F$ ig 5), indicating that of all in vitro expanded anti-host CTL precursors, reactivity is directed towards determınants which are expressed on the patient's non-lymphoid cells after BMT Additionally, CTL lines with clear HLA-A1 restriction proved capable of lysis of unrelated HLA-A1, HA-3 ${ }^{+}$ keratınocytes No cytotoxicity toward donor keratınocytes was found for any of the CTL lines (data not shown) 


\section{Discussion}

PBL of patients after HLA-Identical BMT are known to contain CTLs reactive to host $\mathrm{mH}$ antigens present on patients' pre-transplant PBL $(6,8)$ The observation that skin cells of a healthy full donor chimera after HLA identical BMT expressed a patient specific $\mathrm{mH}$ antigen prompted us to monitor tolerance to host $\mathrm{mH}$ antigens in vitro In this patient we for the first time quantified graft-versus-host CTL reactivity in a primary in vitro assay using LDA $A$ relatively high ant-host CTLp frequency was found during aGVHD, which gradually disappeared in time and became undetectable in PBL of the healthy patient after BMT (Fig 2a) By contrast, the CTLp frequency aganst alio-HLA antigens was found to be decreased shortly after BMT (FIg 2) This is consistent wiht earlier data, indicating a compromised $T$ cell response to allo-HLA antigens after BMT (14) The striking relative predominance of anti-host CTLS shortly after BMT might be explaned by preferential clonal expansion of these donor $T$ cells which are activated by host antigens presumably on residual BM derived host antigen presenting cells (APC) (2) An indication of the nature of the antigens giving rise to this high anti-host CTLp frequency was obtaned by analyzing host reactive $L D$ cultures for HLA restriction (Fig 4) and tissue recognition (Fig 5) Recognition of the patient's post-BMT dermal fibroblasts in vitro (FIg 5) indicated that all CTL precursors detected in PBL have $\mathrm{mH}$ antigen specificties which enable them to interact with non-lymphoid tissue of host origin in vivo After the initial 5 months of aGVHD this patient is disease free, having a normalized allo HLA CTLP frequency, whereas the antt-host CTLp frequency could no longer be measured (Figs 2 and 3 ) This in vitro unresponsiveness to host antigens could reflect an in vivo state where host reactive T cells have been deleted or, alternatively, have been rendered inactive via specific or non specific suppressor mechanisms the presence of suppressor cells cannot be ruled out merely on the basis of LD analysis following single hit kinetics (15) We did not perform any in vitro suppressor cell assays and cannot discriminate between anergy, active suppression, or clonal deletion of host reactive cells in this patient Studies in murine radiation chimeras have suggested a need for etther specific $(3,4)$ or non-specific (as reviewed in 4 ) suppressor cells to maintan graft - host tolerance after transplantation across minor histocompatibility barners In man, a role for antigen specific suppressor cells was suggested in an early study by Tso et al (5), who demonstrated a correlation between the presence of suppressor cells and long-term graft - host tolerance However, it should be stressed that, whatever is the underlying mechanism in this patient, we do not know whether the observed tolerization of the anti-host CTL response in vitro is causally related to the development of graft - host tolerance in vivo Using polyclonal cell cultures, van Els et al (7) showed in a study comprising 16 patients that the absence of host reactive CTLs was not sufficient to ensure long term graft-host tolerance We are currently investigating a panel of patients in order to settle the question whether the anti-host CTLp frequency is correlated with the In vivo state of graft - host reactivity after HLA identical BMT

Under the assumption that this is the case, we would like to propose a hypothetical mechanism for tolerance induction to $\mathrm{HA}-3$ and other persistent $\mathrm{mH}$ antigens in this patient Keratınocytes, fibroblasts, and many other so-called 'non classical' APC (16) have been found to have no or litle capacity of $\mathrm{T}$ cell activation, even after IFN $\gamma$ induced HLA class II expression (17,18) HLA class II expresingng keratinocytes (also found in aGVHD-affected skin', 16) were èven found to tolerize hapten-specific T cell clonesin vitro (19) in the full donor chımera studied here non-hematopoietic host tissues provide the only source of host $\mathrm{mH}$ antigens after BMT Indirect presentation of antigenic fragments to donor T cells by donor APC which have bound and reprocessed shed host antigen could occur after BMT However, though presentation via this mechanism to donor T cells may very well take place for class $I I$ restricted exogenous products, it is less likely to occur in the case of MHC class I restricted endogenous $\mathrm{mH}$ antigens Direct presentation of host $\mathrm{mH}$ antigen by parenchymal host tissues functioning as inadequate APCs could result in tolerization of anti-host CTLS Induced during BM engraftment According to this hypothesis, the induction of long-term graft - host tolerance versus reactivity after BMT across mınor histocompatiblity baprriers would depend on the tissue distribution of the $\mathrm{mH}$ antigens in question We are currently investigating the tissue distribution of human $\mathrm{mH}$ antigens

Finally, from a methodological point of view this case study reveals that it is possible to use LD methods to study CTL responses to $\mathrm{mH}$ antigens triggered by BMT if generally applicable, this would mean that the repertore of host reactive CTLs could be analyzed systematically and quantitatively and perhaps it would even become possible to distinguish 'major' $\mathrm{mH}$ antigens, $1 \mathrm{e}$ those that trigger a strong $\mathrm{T}$ cell response in vivo

\section{Acknowledgments}

We thank $J$ and $G$ Ten Hove for their extraordinary cooperatıon Advice on keratınocyte culturing from $\operatorname{Dr} M$ Ponec and $\mathrm{J}$ Kempenaar is also gratefully acknowledged This work was supported by the Macropa Foundation and the $J$ A Cohen Institute for radiopathology and radiation protection (IRS)

\section{Abbreviations}

$\begin{array}{ll}\text { aGVHD } & \text { acute graft versus host disease } \\ \text { APC } & \text { antigen presenting cell } \\ \text { BMT } & \text { bone marrow transplantation } \\ \text { CML } & \text { cell mediated lympholysis } \\ \text { CTL(p) } & \text { cytotoxic T lymphocyte (precursor) } \\ \text { EBV LCL } & \text { Epstein - Barr virus lymphocyte cell Ine } \\ \text { LDA } & \text { limitıng dilution analysis } \\ \text { mH antigen } & \text { minor histocompatibility antigen } \\ \text { PBL } & \text { peripheral blood leukocytes } \\ \text { PHA } & \text { phytohemagglutinin } \\ \text { PMNC } & \text { polymorphonuclear cells } \\ \text { RC } & \text { responder cells } \\ \text { SC } & \text { stimulator cells }\end{array}$

\section{References}

1 Deeg H J Tsol M S and Storb R 1984 Mechanisms of tolerance In marrow transplantation Transplant Proc 16933

2 Korngold R and Sprent J 1983 Lethal GVHD across minor histocompatibitity barriers nature of the effector cells and role of the H 2 complex Immunol Rev 715

3 Halle Pannenko $O$ Pritchard L L Bruley Rossat M Berumen $L$ and Motta R 1985 Parameters involved in the induction and abrogation of the lethal graft versus host reaction directed by non $\mathrm{H}_{2}$ antigen Immunol Rev 8859 
4 Perreault, C Belanger R Gyger M Allard A and Brochu S 1989 The mechanısm of graft - host tolerance in murine radiation chımeras transplanted across minor histocompatıbility barriers Bone Marrow Transplant 483

5 Tsol M-S, Storb R, Dobbs, S and Thomas, E D 1981 Specific suppressor cells in graft - host tolerance of HLA identical marrow transplantation Nature 292355

6 Goulmy, E 1988 Minor histocompatiblity antigens in man and their role in transplantation Transplant Rev 229

7 van Els, C A C M, Bakker, A, Zwinderma, A H, Zwaan, A H Zwaan $F E$, van Rood, J J, and Goulmy E 1990 Effector mechanisms in graft vs host disease in response to minor histocompatibility antigens I Absence of correlation with cytotoxic effector cells Transplantation 5062

8 Tsol, M-S , Storb, R, Santos E, and Thomas, E 1983 Anthost cytotoxic cells in patients with acute graft versus-host disease after HLA identical marrow grafting Transplant Proc $\$ 1484$

9 van Els $C A C M$. Bakker $A$, Zwinderman $A H$, Zwaan, $F E$, van Rood J J , and Goulmy, E 1990 Effector mechanısms in graft vs host disease in response to minor histocompatibility antigens II Evidence for a possible involvement of proiferative $T$ cells Transplantation 5067

10 Gebel, H M , Kaizer, H , and Landay, A L 1987 Characterızation of crculating suppressor T lymphocytes in bone marrow transplant recipients Transplantation 43258

11 de Bueger, $M$ M , van Els C A C M . Kempenaar, J, Ponec, $M$, and Goulmy, E 1990 A new sensitive assay for measurement of cell mediated cytotoxicity to intact layers of cultured human keratınocytes $\checkmark$ Immunal Methods 127117
Tolerization of host reactive anti-minor CTLS after BMT

12 Russel J H Musil L, and McCulley, D E 1988 Loss of adhesion, a novel and distinct effect of the cytotoxic $T$ lymphocyte-target interaction $J$ Immunol 140427

13 Zhang $L, L, S G$, Vandekerkhove, B, Termijtelen, A, van Rood, $\mathrm{J} J$, and Claas, $F \mathrm{H} J 1989$ Analysis of cytotoxic T cell precursor frequencies directed against individual HLA-A and -B alloantıgens $J$ Immunol Methods 12139

14 Tilkın, A F Bagot, M, Dreyfus, F, Kaybanda, M, Cordonnıer, C , Vernant J P, and Levy, JP 1987 Reconstitution of cytotoxic T lymphocyte activity following allogeneic bone marrow transplantation in man Transplantation 44303

15 Vandekerckhove, B A E, Datema, G, Goulmy, E, Persijn, G, van Rood, J J, Claas, F H J, and de Vries, J E 1990 Analysis of the donor-specific cytotoxic T-lymphocyte repertore in a patient with a long term surviving allograft $J$ Immunol 1441288

16 Mueller, D L, Jenkıns, M K, and Schartz, R H 1989 Clonal expansion versus functional clonal inactivation a costimulatory signalling pathway determines the outcome of a $T$ cell receptor occupancy Annu Rev Immunol 7445

17 Breathnach, S M, Shimada, S, Kovac, Z, and Katz, S I 1986 Immunologic aspects of acute cutaneous GVHD decreased density and antigen presenting function of $\mathrm{la}+\mathrm{LC}$ and absent antigen presenting function of la + keratinocytes $J$ Invest Dermatol 86226

18 Geppert, T D and Lipsky, P E 1987 Dissection of defective antigen presentation by interferon gamma treated fibroblasts $J$ Immunol 138385

19 Gaspan, A A, Jenkıns, M K, and Katz, S | 1988 Class II MHC bearıng keratınocytes induce antıgen-specific unresponsiveness in hapten specific Th1 clones $J$ Immunol 1412216 